\title{
Histone acetylation may suppress human glioma cell proliferation when p21WAF/Cip1 and gelsolin are induced
}

\author{
Hideki Kamitani, ${ }^{1}$ Seijiro Taniura, Kenji Watanabe, Makoto Sakamoto, Takashi \\ Watanabe, and Thomas Eling \\ Department of Neurosurgery, Institute of Neurological Sciences, Faculty of Medicine, Tottori University, \\ Yonago, 683-8504 Japan (H.K., S.T., K.W., M.S., T.W.); Laboratory of Molecular Carcinogenesis, National \\ Institute of Environmental Health Sciences, Research Triangle Park, NC 27709 (S.T., T.E.)
}

Histone deacetylase inhibitors that increase histone acetylation on transformed cells are being investigated as unique anticancer drugs. The aim of this investigation was to evaluate an antiproliferative activity of the histone deacetylase inhibitors sodium butyrate (NaBT) and trichostatin A on 5 glioma cell lines, T98G, A172, U-87 MG, U-118 MG, and U-373 MG, with the examination of the altered expressions in $p 21$ and gelsolin genes. Treatment with 5-mM NaBT and $40 \mathrm{ng} / \mathrm{ml}$ trichostatin A for $48 \mathrm{~h}$ caused more than a $50 \%$ growth inhibition in 5 cell lines as measured by cell proliferation assays. An increase in histone acetylation was confirmed in each cell line. After treatment with $5 \mathrm{mM} \mathrm{NaBT}$, T98G, A172, and U118 cells undergo apoptosis as indicated by DNA ladder formation. Treatment with $\mathrm{NaBT}$ and trichostatin A also decreased DNA synthesis as examined by the fluorescence-activated cell sorting analysis in T98G and U87 cells. In addition to the suppression of cell growth, the up regulation of $p 21$ and gelsolin expression was observed after treatment with $\mathrm{NaBT}$, especially in T98G cells. Maximum expression of $p 21$ and gelsolin was observed within $24 \mathrm{~h}$ after treatment. Results from our in vitro studies indicate that the treatment of human glioma cells with one of the histone deacetylase inhibitors suppresses cell growth with decreasing DNA synthesis and

Received 9 October 2001, accepted 9 January 2002.

${ }^{1}$ Address correspondence and reprint requests to Hideki Kamitani, 36-1, Nishi-cho, Yonago, Tottori 683-8504 Japan.

${ }^{2}$ Abbreviations used are as follows: FBS, fetal bovine serum; HDAC, histone deacetylase; NaBT, sodium butyrate; SDS-PAGE, sodium dodecyl sulfate-polyacrylamide gel electrophoresis; TSA, trichostatin A. stimulates apoptosis, and that associated molecular mechanisms responsible for these effects include increased histone acetylation as well as enhanced expression of p21 and gelsolin. Neuro-Oncology 4, 95-101, 2002 (Posted to Neuro-Oncology [serial online], Doc. 01-056, March 1, 2002. URL <neuro-oncology.mc. duke.edu>)

A fter surgical resection of glioblastomas and anaplastic gliomas, chemotherapy in combination with radiotherapy is currently one of the prime adjuvant treatments (Brandes et al., 2000). Nitrosourea and platinum drugs are widely administered to glioma patients (Frenay et al., 2000; Shapiro et al., 1989; Takakura et al., 1986), but are not particularly effective as indicated by the lack of progress that has been made in improving the efficacy of chemotherapy for malignant gliomas during the past 25 years (Brandes et al., 2000). New modalities of anticancer drugs are thus required to advance treatment of malignant gliomas.

HDAC $^{2}$ inhibitors that induce acetylation of nuclear histones play a crucial role in gene expression (Csordas, 1990) and are novel antiproliferative agents that could be developed into drugs to treat cancer. The HDAC inhibitor $\mathrm{NaBT}$ has been shown to induce cell cycle arrest or differentiation in various tumor cells (Riggs et al., 1977). Another HDAC inhibitor, TSA, strongly induces cell differentiation in erythroleukemia cells (Yoshida et al., 1987). The molecular target for both agents is the enzyme histone deacetylase, which regulates histone acetylation. These agents inhibit the deacetylase and are thus classified as HDAC inhibitors (Ausio and van Holde, 1986). As a result of this activity, HDAC 
inhibitors modify the transcriptional regulation for several genes, including $\gamma$-globin (MaCaffrey et al., 1997), p21 (Archer et al., 1998), gelsolin (Saito et al., 1999), c-MYB (Thompson et al., 1998), and 15-lipoxygenase (Kamitani et al., 1998). Because the growth-inhibitory effect and the modification of gene activation occur simultaneously by treatment with HDAC inhibitors, these agents have attracted considerable interest among oncologists as promising anticancer drugs.

The interest in HDAC inhibitors as anticancer drugs evoked the discovery and development of new drugs, such as trapoxin (Kijima et al., 1993), depudecin (Kwon et al., 1998), FR901228 (Nakajima et al., 1998), oxamflatin (Kim et al., 1999), MS-27-275 (Saito et al., 1999), suberoylanilide hydroxamic acid (Butler et al., 2000), and apicidin (Han et al., 2000). These drugs and the classical HDAC inhibitors were evaluated for anticancer activity toward various tumors in vitro and in vivo, but little information is known about the effect of HDAC inhibitors on gliomas.

Here we have studied mainly the effect of $\mathrm{NaBT}$, a representative HDAC inhibitor, on 5 glioma cell lines. Our analysis included measurement of cell growth, cell cycle analysis, and apoptotic response. Furthermore, the expression of $p 21$ (Waldman et al., 1995) and gelsolin (Sakai et al., 1999), which function as cell cycle regulators, were examined in glioma cell lines after treatment with HDAC inhibitors.

\section{Materials and Methods}

\section{Cell Culture}

The human malignant glioma cell lines, T98G, A172, U-118 MG, U-373 MG, and U-87 MG, were obtained from the American Type Culture Collection (ATCC; Manassas, Va.). The cells were grown in Eagle's minimal essential medium, 10\% FBS (Summit, Fort Collins, Colo.) with 1-mM sodium pyruvate (Life Technologies, Inc., Paisley, U.K.) The media for cells contained gentamicin $(1 \mathrm{mg} / 100 \mathrm{ml}$, Life Technologies, Inc.). The compounds of HDAC inhibitors NaBT and TSA were obtained from Sigma (St. Louis, Mo.). The NaBT and TSA were solubilized by phosphate-buffered saline and dimethylsulfoxide, respectively.

\section{Cell Proliferation Assay}

The cell growth and cytotoxicity were assessed by the cell proliferation assay solution, which is commercially available as CellTiter 96 AQueous One Solution (Promega, Madison, Wis.). In a 96-well plate, each well was seeded with 5000 cells in $100 \mu \mathrm{l}$ media and was allowed to incubate for $24 \mathrm{~h}$ at $37^{\circ} \mathrm{C}$ before replacing the FBS media with media containing the HDAC inhibitors. CellTiter solution $(20 \mu \mathrm{l})$ was added to each well, the plate was incubated for $1 \mathrm{~h}$ at $37^{\circ} \mathrm{C}$, and the absorbance was recorded at $490 \mathrm{~nm}$ using a 96 -well plate reader. The ratio of the absorbance value of each HDAC inhibitor treatment versus FBS-conditioned cells was plotted on the proliferation curve.

\section{DNA Fragmentation Assay}

After treatment with HDAC inhibitors, the floating cells were collected and sedimented. Cell pellets were washed, resuspended in cell lysis buffer $(10-\mathrm{mM}$ Tris-HCl [pH 7.4], 10-mM EDTA [pH 8.0], 0.5\% Triton X-100], and incubated. RNase A $(0.5 \mathrm{mg} / \mathrm{ml})$ and proteinase $\mathrm{K}$ $(0.5 \mathrm{mg} / \mathrm{ml})$ were added, and the pellets were incubated for $2 \mathrm{~h}$. DNA was precipitated by ethanol and resuspended in distilled water; $1 \times 10^{6}$ cells were electrophoresed on a $1.5 \%$ agarose gel. The gel was stained with ethidium bromide, and the DNA was visualized using a UV transilluminater.

\section{Cell Cycle Analysis by Flow Cytometry}

Cells were harvested by trypsinization, and the cell suspension was washed twice in phosphate-buffered saline, then fixed in $70 \%$ ice-cold ethanol, and stored at $4^{\circ} \mathrm{C}$. Before analysis, fixed cells were treated with RNaseA $(0.5 \mathrm{mg} / \mathrm{ml})$ and stained with propidium iodide $(50 \mathrm{mg} / \mathrm{ml})$. Cell cycle analysis was performed with FACSort equipped with CellQuest software (Becton Dickinson, San Jose, Calif.) by gating on an area-versus-width dot plot to exclude cell doublets and other clumps. Cells (7500) were examined and sub- $\mathrm{G}_{1}$ values were obtained using standard histogram analysis. Cell cycle analysis was done by a ModFit LT version 2.0 (Verity Software House, Inc., Topsham, Me.).

\section{Histone Isolation and Fractionation}

The cell pellets were washed twice with $0.5 \mathrm{ml}$ lysis buffer (10 mM Tris [pH 8.0] and $13 \mathrm{mM}$ EDTA) and resuspended in cold distilled water; sulfuric acid was added to $0.4-\mathrm{N}$ final concentration. The lysates were incubated on ice for $1 \mathrm{~h}$ and centrifuged $(10,000 \mathrm{~g}$, $5 \mathrm{~min})$. Total histones were precipitated from the supernatants with $10 \times$ volumes of acetone at $-20^{\circ} \mathrm{C}$ overnight. The precipitated histones were collected by centrifugation, dried, and resuspended in distilled water. Histone acetylation was evaluated by fractionating histones on acid/urea/polyacrylamide gels. The lower gel was $15 \%$ acrylamide, $2.5 \mathrm{M}$ urea, $5 \%$ acetic acid with $0.5 \% \quad N, N, N^{\prime}, N^{\prime}$-tetramethylethylenediamine, and $0.12 \%$ ammonium persulfate. The stacking gel was $7.5 \%$ acrylamide, $2.5 \mathrm{M}$ urea, $5 \%$ acetic acid, $0.75 \%$ $N, N, N$ ', $N$ '-tetramethylethylenediamine, and $0.15 \%$ ammonium persulfate. After samples were loaded, the gel was run for $12 \mathrm{~h}$ at $80 \mathrm{vol}$. Both histone and histone $\mathrm{H} 4$ derived from calf thymus were purchased from Boehringer-Mannheim (Indianapolis, Ind.) and were loaded as standards for unacetylated histone protein. Gels were fixed and stained for $1 \mathrm{~h}$ in $0.25 \%$ Coomassie blue $/ 10 \%$ acetic acid $/ 40 \%$ methanol by volume, then destained with repeated changes of acetic acid/methanol.

\section{SDS-PAGE and Immunoblot Analysis}

The antibodies for immunoblot analysis were obtained from Santa Cruz Biotechnology (Santa Cruz, Calif.). The polyclonal goat anti- $p 21$ antibody, the polyclonal goat antigelsolin antibody, and the polyclonal goat anti-actin 
antibody were used in this study. For preparation of total proteins, cells were washed twice with ice-cold phosphate-buffered saline and lysed in protein lysis buffer: $50 \mathrm{mM}$ Tris- $\mathrm{HCl}$ (pH 8.0); $150 \mathrm{mM} \mathrm{NaCl} ; 0.1 \%$ sodium dodecyl sulfate; $1 \%$ Nonidet P-40; $0.5 \%$ sodium deoxycholate; $1 \mathrm{mg} / \mathrm{ml}$ leupeptin and aprotinin; and $0.5 \mathrm{mM}$ phenylmethylsulfonyl fluoride. The lysates were sonicated 4 times for $20 \mathrm{~s}$ at $50 \%$ power. Protein content was quantified by the bicinchronic acid method using bicinchoninic acid (BCA) protein assay reagent (Pierce, Rockford, Ill.) and bovine serum albumin as a standard. Aliquots of the protein preparation were boiled in protein sample buffer: $9 \%$ sodium dodecyl sulfate; $15 \%$ glycerol; $30 \mathrm{mM}$ Tris$\mathrm{HCl}(\mathrm{pH} 7.8) ; 0.05 \%$ bromophenol blue; $6 \% \beta$-mercaptoethanol, and separated by $8 \%$ or $12 \%$ SDS-PAGE. Proteins were transferred onto Hybond-enhanced chemiluminescence nitrocellulose membrane (ECL; Amersham, Arlington Heights, Ill.). Blots were blocked with $10 \%$ nonfat dry milk (Bio-Rad, Hercules, Calif.) in Trisbuffered saline containing $0.1 \%$ Tween 20 and washed. The blots were then incubated in $1 \%$ milk in Tween 20 with each primary antibody that cross-reacts with human-derived proteins (diluted by 1:1000 for $p 21$ and gelsolin; 1:2000 for actin). The blots were incubated with antigoat IgG horseradish peroxidase-linked secondary antibody (Amersham) (diluted by 1:5000). The Amersham ECL system was used, and the bands were detected by exposure to Hyperfilm-MP (Amersham). The optimal density of each band was determined by a numerical value using the National Institutes of Health (Bethesda, Md.) imaging system. The value for each band density was normalized against the corresponding actin signal.

\section{Results}

\section{NaBT and TSA Inbibit the Cell Growth of Human Glioma Cell Lines}

The growth inhibitory effect of HDAC inhibitors was evaluated in 5 cell lines, U-87 MG, T98G, U-118 MG, A172, and U-373 MG, after treatment with various concentrations of NaBT and TSA. The cell growth was estimated by a modified 3-(4, 5-dimethylthiazol-2-yl)-5-(3 carboxymethoxyphenyl)-2-(4-sulfophenyl)-2H-tetrazolium method after treatment with 0.2 , 1 , or $5 \mathrm{mM} \mathrm{NaBT}$ and compared with corresponding cells grown in serum containing FBS medium (Fig. 1A). At $0.2 \mathrm{mM}$ and higher $\mathrm{NaBT}$, all cells showed at least $50 \%$ inhibition of the cell growth at 96 h. In contrast, U-87 MG, T98G, and A172 cells showed temporary increases in cell growth with $1 \mathrm{mM} \mathrm{NaBT}$, and for all of the cell lines, $1 \mathrm{mM} \mathrm{NaBT}$ exhibited a smaller inhibitory effect than $0.2 \mathrm{mM} \mathrm{NaBT}$. Consequently, with $5 \mathrm{mM} \mathrm{NaBT}$, more than $70 \%$ inhibition of the cell growth was observed in all cell lines at $96 \mathrm{~h}$ after treatment. The growth inhibition observed in the glioma cells by $\mathrm{NaBT}$ treatment did not occur in a dosedependent manner. For TSA, $40 \mathrm{ng} / \mathrm{ml}, 200 \mathrm{ng} / \mathrm{ml}$, and $1 \mathrm{\mu g} / \mathrm{ml}$ amounts were given to the 5 glioma cell lines, and cell growth in comparison with the FBS condition was examined (Fig. 1B). With $40 \mathrm{ng} / \mathrm{ml}$ TSA, U-87 MG, and T98G cells showed less than $60 \%$ inhibition of cell growth, whereas the other 3 cell lines showed more than
$80 \%$ inhibition at $96 \mathrm{~h}$, indicating a minor difference in drug sensitivity between the cells. In contrast, $200 \mathrm{ng} / \mathrm{ml}$ and $1 \mu \mathrm{g} / \mathrm{ml} \mathrm{TSA}$ induced strong inhibition (more than $90 \%)$ cell growth in all cells.

\section{HDAC Inbibitors Induce Growth Arrest and Apoptosis in Glioma Cells}

Because growth inhibition was observed in glioma cells after treatment with HDAC inhibitors, we used flow cytometry to determine whether the HDAC inhibitors affected the cell cycle and used DNA fragmentation assay to measure the apoptosis induced. T98G and U-87 MG cells were examined to clarify the populations of cell cycle by HDAC inhibitors. Treatment with $5 \mathrm{mM} \mathrm{NaBT}$ for $24 \mathrm{~h}$ decreased the S-phase population from $31.0 \%$ to $9.2 \%$ and from $33.0 \%$ to $20.0 \%$ in T98G and U-87 MG cells, respectively, whereas treatment with $200 \mathrm{ng} / \mathrm{ml}$ TSA for $24 \mathrm{~h}$ decreased the S-phase population from $31.0 \%$ to $17.0 \%$ and from $33.0 \%$ to $16.0 \%$ in T98G and U-87 MG cells, respectively (Table 1). Moreover, populations in $\mathrm{G}_{0}-\mathrm{G}_{1}$ and $\mathrm{G}_{2}-\mathrm{M}$ phase were increased at $24 \mathrm{~h}$ after treatment with HDAC inhibitors.

After the cells were treated with $5 \mathrm{mM} \mathrm{NaBT}$, DNA from the floating cells in each glioma cell line was loaded on a $1.5 \%$ agarose gel, and DNA ladder formation was visualized as shown in Fig. 2A. Clear ladder formation was visible in T98G, A172, and U118 cells, indicating that the cells underwent apoptosis. Ladder formation in U-87 MG and U-373 MG was not as clear, but we were able to see slight ladder bands. This finding suggests that the apoptotic cell population is small in U-87 MG and U-373 MG after treatment with HDAC inhibitors.

\section{Histone Acetylation}

In each of the 5 cell lines, acetylation of histone was evaluated by fractionation of histones and analysis of the $\mathrm{H} 4$ histone fraction. The nuclear protein was extracted from the cells after each treatment with FBS or $5 \mathrm{mM}$ $\mathrm{NaBT}$ for $20 \mathrm{~h}$ and was loaded on acid/urea polyacrylamide gels that reveal acetylated $\mathrm{H} 4$ as 4 slower migrating fractions. The histones from FBS-cultured cells showed only a single $\mathrm{H} 4$ band, whereas the histones isolated from NaBT-cultured cells fractionated into $4 \mathrm{H} 4$ bands (Fig. 3). This finding indicates that NaBT induced histone acetylation in the glioma cells. The results also suggest that the increase in histone acetylation by one of the HDAC inhibitors is implicated in growth arrest and stimulation of apoptosis.

\section{Up Regulation of p21 and Gelsolin Expression by HDAC Inhibitors}

The expression of $p 21$ and of gelsolin was evaluated in 5 different glioma cells before and after treatment with $5 \mathrm{mM} \mathrm{NaBT}$. Total protein was extracted $48 \mathrm{~h}$ after treatment with or without $\mathrm{NaBT}$ and was examined by immunoblot analysis as shown in Fig. 4. Equal protein loading was confirmed by the uniformity of the actin 

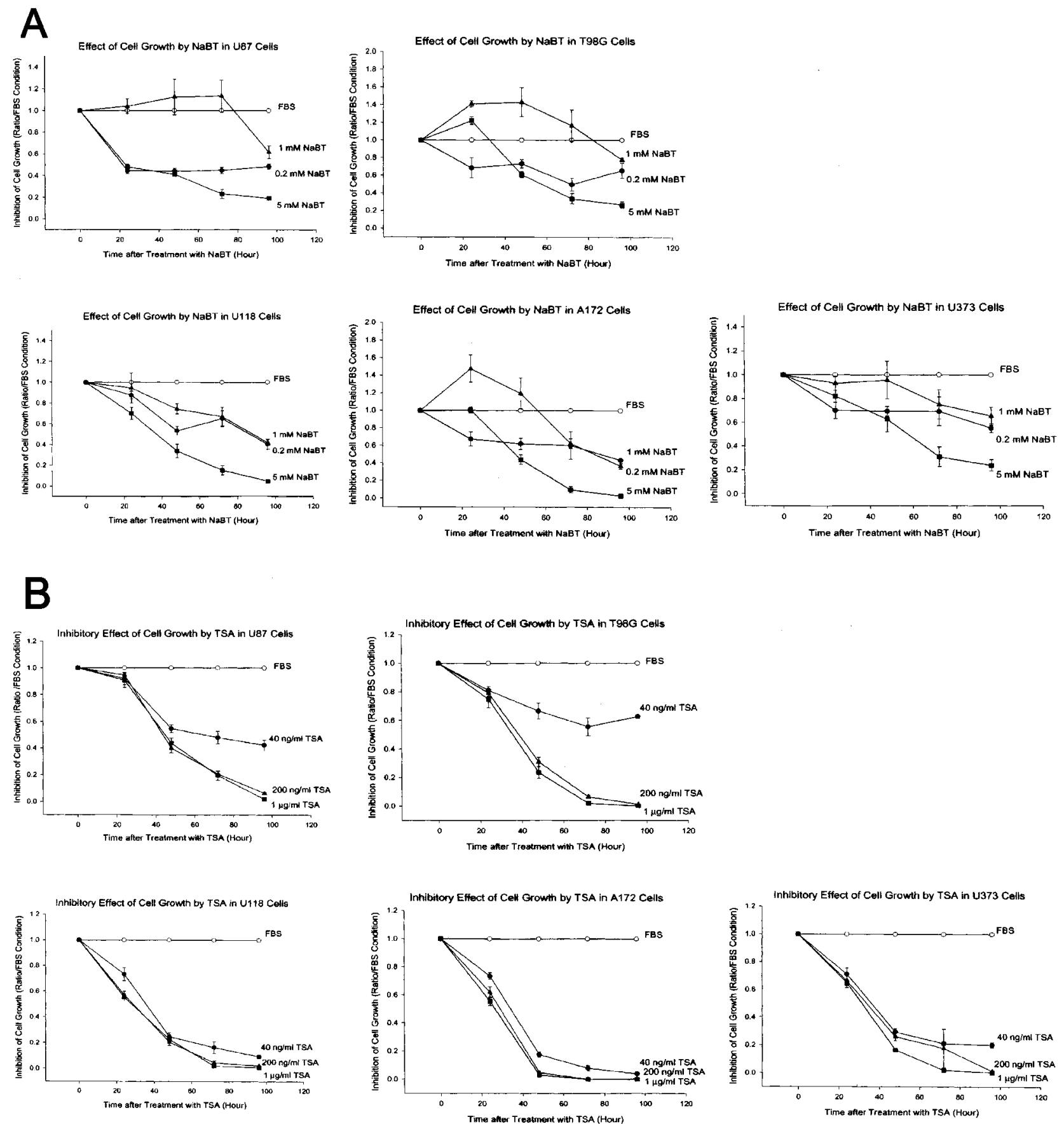

Fig. 1. Effects of HDAC inhibitors on human glioma cells in vitro. The analysis of the cell proliferation was evaluated by 3-(4,5-dimethylthiazol2-yl)-5-(3 carboxymethoxyphenyl)-2-(4-sulfophenyl)-2H-tetrazolium(MTS) assay. The viability of the cells is expressed as the ratio of the number of viable cells with $\mathrm{NaBT}$ treatment compared to that without treatment. The graph shows the representative data from the 3 independent experiments. Means \pm SE of 5 numbers were plotted for each cell line. A. Cells (U-87 MG, T98G, U-118 MG, A172, and U-373 MG) were treated with $\mathrm{NaBT}$ once at time 0 at the following concentrations: FBS (control), $0 ; 0.2 \mathrm{mM} \mathrm{NaBT}, \bullet ; 1 \mathrm{mM} \mathrm{NaBT}, \mathbf{\Delta} ; 5 \mathrm{mM} \mathrm{NaBT}, \mathbf{\square}$. B. Cells (U-87 MG, T98G, U-118 MG, A172, U-373 MG) were treated with TSA once at time 0 at the following concentrations: FBS (control), $0 ; 40 \mathrm{ng} / \mathrm{ml}$ $\mathrm{TSA}, \bullet ; 200 \mathrm{ng} / \mathrm{ml} \mathrm{TSA}, \boldsymbol{\Delta} ; 1 \mu \mathrm{g} / \mathrm{ml}$,

expression. After $\mathrm{NaBT}$ treatment, all cells showed increased expression of both gelsolin and $p 21$, the only exception being U-118 MG, which showed slightly decreased expression (0.73-fold band density). Increased expression of $p 21$ was most evident in U-87 MG, T98G, and A172 cells, which showed 14.4-, 3.83-, and 8.28- fold band density, respectively. We next studied the temporal expression pattern of $p 21$ and gelsolin in T98G cells after treatment with $\mathrm{NaBT}$ for $0,24,48,72$, and $96 \mathrm{~h}$ (Fig. 5). Interestingly, the maximum expression of p21 and gelsolin occurred after treatment for $24 \mathrm{~h}$. Then expression of $p 21$ was down regulated at $48 \mathrm{~h}$ after 


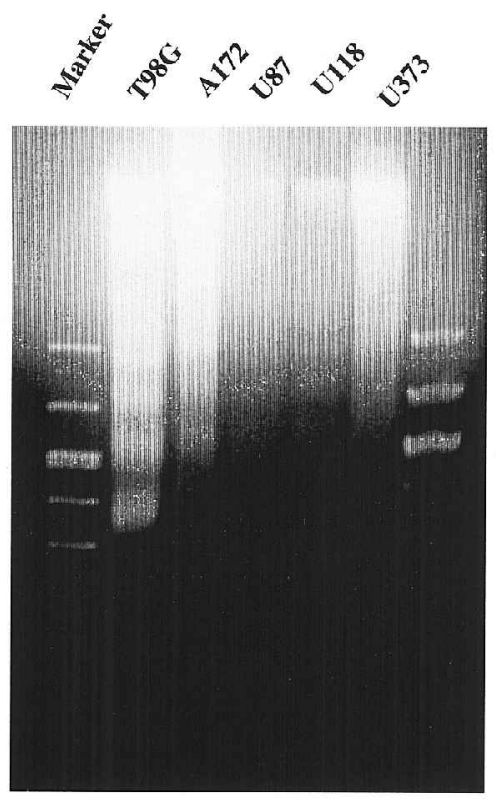

Fig. 2. DNA ladder formation on $1.5 \%$ agarose gel for T98G, A172, U-87 MG, U-118 MG, and U-373 MG cells. Floating cells $\left(1 \times 10^{6}\right)$ were collected and loaded on an agarose gel $72 \mathrm{~h}$ after treatment with $5 \mathrm{mM} \mathrm{NaBT}$. Ladder formation is visible in T98G, A172, and U-118 MG cells, indicating an apoptotic response.

treatment, whereas the expression of gelsolin was unchanged after $48 \mathrm{~h}$. Because the inhibition of cell growth increased with time during $96 \mathrm{~h}$ of NaBT treatment, the up regulation of $p 21$ and gelsolin precedes the biological events in T98G cells.

\section{Discussion}

In this study, we were able to confirm the following results in human glioma cells: HDAC inhibitors inhibit cell proliferation with decreasing DNA synthesis and stimulate apoptosis; NaBT, a classical HDAC inhibitor, increases histone acetylation; HDAC inhibitors up regulate the expression of $p 21$ and gelsolin; and changes in $p 21$ and gelsolin expression are associated with inhibitory effects on cell growth and apoptosis.

The growth inhibition was apparent in glioma cells by treatment with both $\mathrm{NaBT}$ and TSA, but a paradoxical effect on cell growth was observed by treatment with NaBT. At $1 \mathrm{mM} \mathrm{NaBT}$, increases in the growth of U-87 MG, A172, and T98G cells were observed, whereas inhibitory effects were observed at higher concentrations. Butyrate is a short-chain fatty acid that is produced in the gastrointestinal tract after fermentation of luminal carbohydrates. Moderate concentrations of butyrate confer a

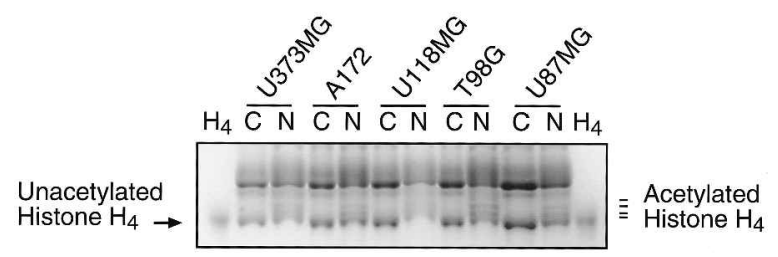

C: Control

$\mathrm{N}$ : NaBT Treatment

Fig. 3. Acetylation of histone $\mathrm{H} 4$ observed on acid/urea/polyacrylamide gel. Nuclear proteins of the glioma cells (U-373 MG, A172, $\mathrm{U}-118 \mathrm{MG}, \mathrm{T} 98 \mathrm{G}, \mathrm{U}-87 \mathrm{MG}$ ) were extracted at $24 \mathrm{~h}$ after treatment with or without $5 \mathrm{mM} \mathrm{NaBT}$. Then $10 \mu \mathrm{g}$ of nuclear protein and the unacetylated $\mathrm{H} 4$ histone (as a standard) were loaded on an acid/ urea/polyacrylamide gel. Acetylated histone $\mathrm{H} 4$ was observed as slower migrating bands compared to unacetylated $\mathrm{H} 4$. C, control (FBS treatment without $\mathrm{NaBT}$ ); $\mathrm{N}$, with $\mathrm{NaBT}$ treatment.

growth advantage on the cells as an energy source, whereas several degrees of millimolar concentration of butyrate primary indicate the character of histone acetylation and suppress growth proliferation of the cells. This mechanism is explained as just a "paradoxical effect" of butyrate (Gibson et al., 1999). On the other hand, TSA showed a clear dose-dependent effect on growth suppression; micromolar concentrations were sufficient to achieve significant inhibition. In addition to growth suppression by $\mathrm{NaBT}$, enhanced apoptosis was observed. Moreover, NaBT and TSA decreased DNA synthesis and delayed cell cycle. Thus, HDAC inhibitors may directly suppress cell proliferation, but could also act to increase programmed cell death. Further investigations are required to elucidate the precise mechanism of the cell death, including assay of caspase.

Previously, NaBT (Hargreaves et al., 1989), phenyl acetate (Stockhammer et al., 1995), and phenyl butyrate (Engelhard et al., 1998) were not recognized as HDAC inhibitors, but were reported to stimulate differentiation by modifying the morphology and cell cycle in glioma cells. In this report, we presented firm evidence that treatment with one of these agents causes increased histone acetylation, and thus, histone acetylation should be implicated in the suppression of cell growth. However, it is still controversial whether acetylation is specific for histone protein (Marks et al., 2000).

The interest in HDAC inhibitors is strongly linked to the finding that HDAC inhibitors alter gene regulation. In this study, we clearly present evidence for the up regulation of $p 21$ and gelsolin, especially in T98G cells after treatment with HDAC inhibitors. The molecular role of the $p 21$ gene is explained as a potential mediator of $p 53$ tumor suppressor function in transformed cells (El-Deiry

Table 1. Cell cycle analysis of T98G and U-87 MG cells after treatment with HDAC inhibitors

T98G cells (\%)

\begin{tabular}{lcccr}
\cline { 2 - 5 } Cell cycle & Sub G1 & G0-G1 & G2-M & \multicolumn{1}{c}{ S } \\
\hline Control & 0.5 & 68.0 & 1.3 & 31.0 \\
NaBT & 1.0 & 80.0 & 10.0 & 9.2 \\
TSA & 3.2 & 65.0 & 18.0 & 17.0 \\
\hline
\end{tabular}




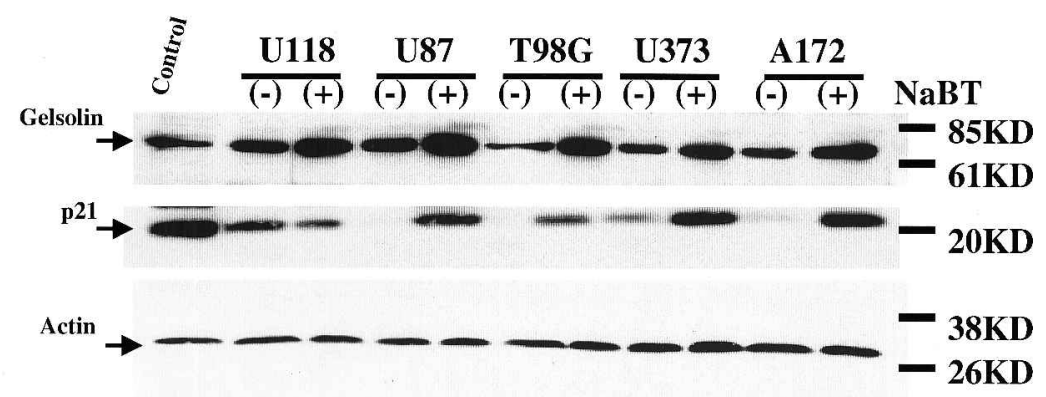

Fig. 4. Immunoblot analysis for evaluation of $p 21$ and gelsolin expression. The glioma cells (U-118 MG, U-87 MG, T98G, U-393 MG, A172) were treated with or without $5 \mathrm{mM} \mathrm{NaBT}$ for $48 \mathrm{~h}$ and total proteins were extracted. Then $20 \mu \mathrm{g}$ of the protein was loaded on $8 \%$ SDS-PAGE for evaluation of gelsolin and actin expression and on 12\% SDS-PAGE for $p 21$ evaluation. Immunoreactive bands were visible at $75 \mathrm{kDa}$ for gelsolin expression and at $21 \mathrm{kDa}$ for $p 21$ expression. The levels of actin expression were used as an internal control for equal loading. Fold increase is $0.73,14.4,3.83,2.10$, and 8.28 in $p 21$ expression, and 1.65, 1.32, 1.48, 1.03, and 1.52 in gelsolin expression for U-118 MG, U-87 MG, T98G, $\mathrm{U}-373 \mathrm{MG}$, and A172 cells, respectively.

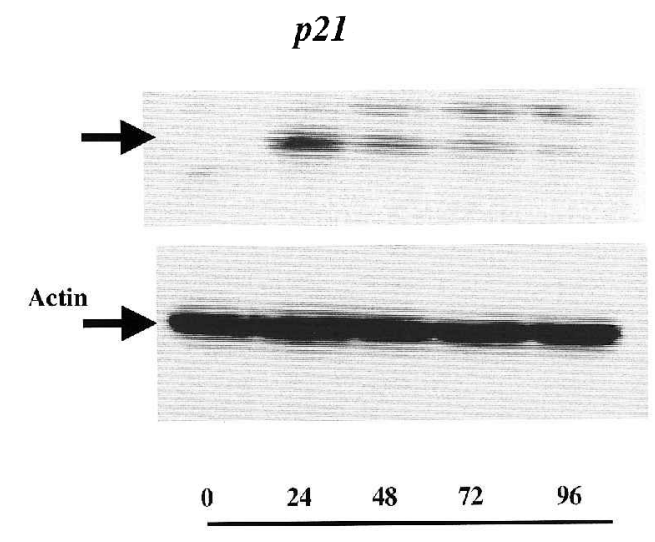

Time (Hour)

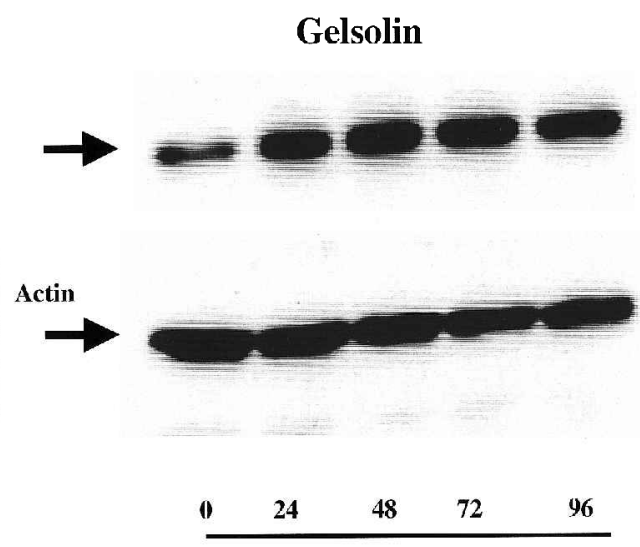

Time (Hour)

Fig. 5. Temporal expression of $p 21$ and gelsolin after treatment with NaBT in T98G cells. The total protein for each time point (0, 24, 48, 72, and $96 \mathrm{~h}$ ) was extracted after treatment with $5 \mathrm{mM} \mathrm{NaBT}$. Then $20 \mu \mathrm{g}$ of the total protein was loaded on $8 \%$ SDS-PAGE to detect gelsolin expression and on $12 \%$ SDS-PAGE to detect $p 21$. The levels of actin expression were used as an internal control for equal loading.

et al., 1993), and Harada et al. (2000) reported growth inhibition after transfection of the $p 21$ gene into glioma cells. These findings indicate $p 21$ negatively alters growth of gliomas, and thus the expression of $p 21$ in T98G cells after treatment with $\mathrm{NaBT}$ may contribute to the growth suppression. The expression of gelsolin as related to cell growth in gliomas is poorly understood. However, recent reports suggest that a down regulation of gelsolin is associated with breast cancer (Asch et al., 1999; Habeck, 1999). Thus, up regulation of both $p 21$ and gelsolin expression by HDAC inhibitors may provide an explanation of growth inhibition in glioma cells. The expression of approximately $2 \%$ of all genes is altered in cultured cells by treatment with HDAC inhibitors (Van Lint et al., 1996). Thus, histone acetylation clearly must alter expression of other genes involved in cell growth, such as c-MYC (Rabizadeh et al., 1993), c-MYB (Thompson et al., 1998), and more.

Future interest would be in the possible application of HDAC inhibitors in gliomas. Because acetylation of histones also occurs in the normal physiological condition, and the natural short fatty acids such as butyric acid exist in the gastrointestinal tract (Gibson et al., 1999), we should not categorize HDAC inhibitors as conventional anticancer drugs. Because some HDAC inhibitors such as phenyl butyrate are actually applied as differentiationinducing agents for thalassemia patients (Olivieri et al., 1997), these drugs may be feasible for use as chemopreventive agents. Retinoid agents for various cancers (Hansen et al., 2000) and selective COX-2 inhibitors for colorectal cancer (Janne and Mayer, 2000) are examples of currently employed chemopreventive agents. In addition, a clinical trial of a synthetic HDAC inhibitor FR901228 has begun for a certain type of T-cell lymphoma (Piekarz et al., 2001). Further fundamental studies, including in vivo experiments, will be required using HDAC inhibitors for clinical application against CNS tumor. Apparently, a device of drug delivery of these agents to CNS is also an important issue for the future.

\section{Acknowledgments}

We thank Dr. Jennifer Nixon in NIEHS (National Institute of Environmental Health Sciences) for her critical reading of the manuscript. 


\section{References}

Archer, S.Y., Meng, S., Shei, A., and Hodin, R.A. (1998) p21(WAF1) is required for butyrate-mediated growth inhibition of human colon cancer cells. Proc. Natl. Acad. Sci. U.S.A. 95, 6791-6796.

Asch, H.L., Winston, J.S., Edge, S.B., Stomper, P.C., and Asch, B.B. (1999) Down-regulation of gelsolin expression in human breast ductal carcinoma in situ with and without invasion. Breast Cancer Res. Treat. 55, 179-188.

Ausio, J., and van Holde, K.E. (1986) Histone hyperacetylation: Its effects on nucleosome conformation and stability. Biochemistry 25, 1421-1428.

Brandes, A.A., Pasetto, L.M., and Monfardini, S. (2000) New drugs in recurrent high grade gliomas. Anticancer Res. 20, 1913-1920.

Butler, L.M., Agus, D.B., Scher, H.I., Higgins, B., Rose, A., Cordon-Cardo, C., Thaler, H.T., Rifkind, R.A., Marks, P.A., and Richon, V.M., (2000) Suberoylanilide hydroxamic acid, an inhibitor of histone deacetylase, suppresses the growth of prostate cancer cells in vitro and in vivo. Cancer Res. 60, 5165-5170.

Csordas, A. (1990) On the biological role of histone acetylation. Biochem. J. 265, 23-38.

El-Deiry, W.S., Tokino, T., Velculescu, V.E., Levy, D.B., Parsons, R., Trent, J.M., Lin, D., Mercer, W.E., Kinzler, K.M., and Vogelstein, B. (1993) WAF1, a potential mediator of p53 tumor suppression. Cell 75, 817-825.

Engelhard, H.H., Homer, R.J., Duncan, H.A., and Rozental, J. (1998) Inhibitory effects of phenylbutyrate on the proliferation, morphology, migration and invasiveness of malignant glioma cells. J. Neurooncol. 37, 97-108.

Frenay, M., Lebrun, C., Lonjon, M., Bondiau, P.Y., and Chatel, M. (2000) Upfront chemotherapy with fotemustine (F)/cisplatin (CDDP)/etopside (VP16) regimen in the treatment of 33 non-removable glioblastomas. Eur. J. Cancer 36, 1026-1031.

Gibson, P.R., Rosella, O., Wilson, A.J., Mariadason, J.M., Rickard, K., and Barkla, D.H. (1999) Colonic epithelial cell activation and the paradoxical effects of butyrate. Carcinogenesis 20, 539-544.

Habeck, M. (1999) Gelsolin: A new marker for breast cancer? Mol. Med. Today 5, 503.

Han, J.W., Ahn, S.H., Park, S.H., Wang, S.Y., Bae, G.-U., Seo, D.-W., Kwon, H.-K., Hong, S., Lee, H.Y., Lee, Y.-W., and Lee, H.-W. (2000) Apicidin, a histone deacetylase inhibitor, inhibits proliferation of tumor cells via induction of p21(WAF1/Cip1) and gelsolin. Cancer Res. 60, 6068-6074.

Hansen, L.A., Sigman, C.C., Andreola, F., Rossa, S.A., Kelloff, G.J., and De Luca, L.M. (2000) Retinoids in chemoprevention and differentiation therapy. Carcinogenesis 21, 1271-1279.

Harada, K., Kurisu, K., Sadatomo, T., Tahara, H., Tahara, E., and Ide, T. (2000) Growth inhibition of human glioma cells by transfection-induced p21 and its effects on telomerase activity. J. Neurooncol. 47, 39-46.

Hargreaves, A.J., Yusta, B., Avila, J., Hesketh, J.E., Aranda, A., and Pascual, A. (1989) Sodium butyrate induces major morphological changes in $C 6$ glioma cells that are correlated with increased synthesis of a spectrin-like protein. Brain. Res. Dev. Brain Res. 45, 291-295.

Janne, P.A., and Mayer, R.J. (2000) Chemoprevention of colorectal cancer. N. Engl. J. Med. 342, 1960-1968.

Kamitani, H., Geller, M., and Eling, T.E. (1998) Expression of 15-lipoxygenase by human colorectal carcinoma Caco-2 cells during apoptosis and cell differentiation. J. Biol. Chem. 273, 21569-21577.

Kijima, M., Yoshida, M., Sugita, K., Horinouchi, S., and Beppu, T. (1993) Trapoxin, an antitumor cyclic tetrapeptide, is an irreversible inhibitor of mammalian histone deacetylase. J. Biol. Chem. 268, 22429-22435.

Kim, Y.B., Lee, K.H., Sugita, K., Yoshida, M., and Horinouchi, S. (1999) Oxamflatin is a novel antitumor compound that inhibits mammalian histone deacetylase. Oncogene 18, 2461-2470.

Kwon, H.J., Owa, T., Hassig, C.A., Shimada, J., and Schreiber, S.L. (1998) Depudecin induces morphological reversion of transformed fibroblasts via the inhibition of histone deacetylase. Proc. Natl. Acad. Sci. U.S.A. 95 , 3356-3361.

McCaffrey, P.G., Newsome, D.A., Fibach, E., Yoshida, M., and Su, M.S. (1997) Induction of gamma-globin by histone deacetylase inhibitors. Blood $\mathbf{9 0}$, 2075-2083.

Marks, P.A., Richon, V.M., and Rifkind, R.A. (2000) Histone deacetylase inhibitors: Inducers of differentiation or apoptosis of transformed cells. J. Natl. Cancer Inst. 92, 1210-1206.

Nakajima, H., Kim, Y.B., Terano, H., Yoshida, M., and Horinouchi, S. (1998) FR901228, a potent antitumor antibiotic, is a novel histone deacetylase inhibitor. Exp. Cell Res. 241, 126-133.

Olivieri, N.F., Rees, D.C., Ginder, G.D., Thein, S.L., Brittenham, G.M., Waye, J.S., and Weatherall, D.J. (1997) Treatment of thalassaemia major with phenylbutyrate and hydroxyurea. Lancet 350, 491-492.

Piekarz, R.L., Robey, R., Sandor, V., Bakke, S., Wilson, W.H., Dahmoush, L., Kingma, D.M., Turner, M.L., Altemus, R., and Bates, S.E. (2001) Inhibitor of histone deacetylation, depsipeptide (FR901228), in the treatment of peripheral and cutaneous T-cell lymphoma: A case report. Blood $\mathbf{9 8 ,}$ 2865-2868.

Rabizadeh, E., Shaklai, M., Nudelman, A., Eisenbach, L., and Rephaeli, A. (1993) Rapid alteration of c-myc and c-jun expression in leukemic cells induced to differentiate by a butyric acid prodrug. FEBS Lett. 328, 225-229.

Riggs, M.G., Whittaker, R.G., Neumann, J.R., and Ingram, V.M. (1977) n-Butyrate causes histone modification in HeLa and Friend erythroleukaemia cells. Nature 268, 462-464.

Saito, A., Yamashita, T., Mariko, Y., Nosaka, Y., Tsuchiya, K., Ando, T., Suzuki, T., Tsuruo, T., and Nakanishi, O. (1999) A synthetic inhibitor of histone deacetylase, MS-27-275, with marked in vivo antitumor activity against human tumors. Proc. Natl. Acad. Sci. U.S.A. 96, 4592-4597.

Sakai, N., Ohtsu, M., Fujita, H., Koike, T., and Kuzumaki, N. (1999) Enhancement of $\mathrm{G} 2$ checkpoint function by gelsolin transfection in human cancer cells. Exp. Cell. Res. 251, 224-233.

Shapiro, W.R., Green, S.B., Burger, P.C., Mahaley, M.S., Jr., Selker, R.G., VanGilder, J.C., Robertson, J.T., Ransohff, J., Mealey, J.S., Jr., and Strike, T.A. (1989) Randomized trial of three chemotherapy and two radiotherapy regimens and two radiotherapy regimens in postoperative treatment of malignant glioma. Brain Tumor Cooperative Group Trial 8001. J. Neurosurg. 71, 1-9.

Stockhammer, G., Manley, G.T., Johnson, R., Rosenbulm, M.K., Samid, D., and Lieberman, F.S. (1995) Inhibition of proliferation and induction of differentiation in medulloblastoma- and astrocytoma-derived cell lines with phenylacetate. J. Neurosurg. 83, 672-681.

Takakura, K., Abe, H., Tanaka, R., Kitamura, K., Miwa, T., Takeuchi, K., Yamamoto, S., Kageyama, N., Handa, H., Mogami, H., Vishimoto, A., Uozumi, T., Matsutani, M., and Nomura, K. (1986) Effects of ACNU and radiotherapy on malignant glioma. J. Neurosurg. 64, 53-57.

Thompson, M.A., Rosenthal, M.A., Ellis, S.L., Friend, A.J., Zorbas, M.I., Whitehead, R.H., and Ramsay, R.G. (1998) c-Myb down-regulation is associated with human colon cell differentiation, apoptosis and decreased $\mathrm{BCl}-2$ expression. Cancer Res. 58, 5168-5175.

Van Lint, C., Emiliani, S., and Verdin, E. (1996) The expression of a small fraction of cellular genes is changed in response to histone hyperacetylation. Gene Expr. 5, 245-253.

Waldman, T., Kinzler, K.W., and Vogelstein, B. (1995) p21 is necessary for the p53-mediated $\mathrm{G} 1$ arrest in human cancer cells. Cancer Res. 55, 5187-5190.

Yoshida, M., Nomura, S., and Beppu, T. (1987) Effects of trichostatins on differentiation of murine erythroleukemia cells. Cancer Res. 47, 3688-3691. 